\title{
Textural and Compositional Studies of Sediments from Parts of the Albian Bima Sandstone, Upper Benue Trough, Nigeria
}

\author{
Overare B. ${ }^{1}$, Etobro A. A. I. ${ }^{2}$, Osokpor J. ${ }^{1}$, Avwenagha E. O. ${ }^{3}$ \& Ogueh E. D. ${ }^{4}$ \\ ${ }^{1}$ Department of Earth Sciences, Federal University of Petroleum Resources, Effurun, Nigeria \\ ${ }^{2}$ Department of Geology, Delta State University, Abraka, Nigeria \\ ${ }^{3}$ Department of Geology, University of Port Harcourt, Nigeria \\ ${ }^{4}$ Department of Geology and Petroleum Studies, Western Delta University, Oghara, Nigeria \\ Correspondence: Overare Brume, Department of Earth Sciences, Federal University of Petroleum Resources, \\ Effurun, Nigeria. E-mail: Overare.brume@fupre.edu.ng
}

Received: September 15, 2014

Accepted: September 29, $2014 \quad$ Online Published: February 28, 2015

doi:10.5539/jgg.v7n1p97

URL: http://dx.doi.org/10.5539/jgg.v7n1p97

\begin{abstract}
Studies were carried out on fresh samples of sandstones from parts of the Bima Sandstone to classify it on the basis of its textural and compositional characteristics. Grain size analysis of samples reveals that they are fine to coarse-grained, moderately sorted to poorly sorted, coarse skewed to strongly fine skewed and very platykurtic to extremely leptokurtic. Thin-section analysis reveals the sandstones to be lithic subarkoses, subarkoses, and lithic arkoses comprising averagely of $66.6 \%$ quartz, $21 \%$ feldspar and $12.4 \%$ rock fragments. The appreciable amount of feldspar, the dominance of subangular to angular grain shape and the poorly sorted nature of the sandstones suggest that they are texturally and mineralogically immature sediments. Bivariate plots of graphic mean versus standard deviation, skewness versus standard deviation and simple sorting versus simple skewness indicates a fluvial origin for sandstones deposited under a moderate to high energy level.
\end{abstract}

Keywords: Bima sandstone, fluvial, immature, poorly sorted

\section{Introduction}

The Benue Trough in Nigeria is an intracratonic linear shaped sedimentary basin that extends from NNE-SSW for about $800 \mathrm{~km}$ in length and $150 \mathrm{~km}$ in width. The valley contains up to $6,000 \mathrm{~m}$ of Cretaceous-Cenozoic sediments of which those pre-dating the Mid-Santonian sediments have been compressionally deformed, faulted and uplifted in several places. The Upper Benue Trough is characterized by a Y shape. One Arm of the Y is the $\mathrm{N} 180^{\circ} \mathrm{E}$ Gongola Arm and the other is the E-W trending Yola Arm.

The origin and evolution of the Benue Trough has been a subject of several publications; King(1950), Cratchly and Jones, (1965), Grant (1971), Burke et al, (1972), Burke and Whiteman (1973), Olade (1975), Freeth (1978), Wright (1981), Ofoegbu (1984), Nwajide (1990) among others, with the rift model being the most widely accepted. However, the views of Benkhelil $(1987,1989)$ suggests that sinistral wrenching was a dominant process for the structural re-adjustment and geometry of the sub-basins recognized in the lower, middle and upper Benue regions.

According to studies carried out by Haruna et al (2013), results from field observation and measurement show the same agent of transportation for the Bima sandstone as they were laid down by river channels while the fine grain ripple- marked and cracked siltstone beds were deposited in flood plains associated with the river channels. This was evidenced from the abundant tabular and few cross beddings, flat beddings and party lineations , ripple and cross lamination found in finer grain sandstones and lenticlar stream deposited sediments which are indicative of fluviatile conditions. Moreso, Haruna et al. (2013) proposed that the Bima Sandstone was derived from the crystalline rocks of the Hawal Massif, Mandara Massif as well as the Adamawa and Cameroun Massifs.

This study focuses on the textural and compositional characteristics of the Bima sandstone, the earliest sedimentary fill of the Yola Arm. The present study was carried out in the Yola area of North-Eastern Nigeria which is entirely underlain by the Bima sandstone Formation. The aim of the study is to classify the sandstones exposed in the study area on the basis of their textural and compositional characteristics. 


\subsection{Location of the Study Area}

The study area (figure 1) lies between longitude $12^{\circ} 35^{\prime} 36^{\prime \prime}$ and $12^{\circ} 38^{\prime} 12^{\prime \prime}{ }^{\circ} \mathrm{E}$ and latitudes $9^{\circ} 22^{\prime} 40^{\prime \prime}$ and $9^{\circ} 20^{\prime}$ $\mathrm{N}$ within the Yola area in Adamawa state, North- eastern Nigeria. The area generally has high relief which is more pronounced in the central, southern and south-eastern parts. The area is well drained by high discharge seasonal streams and rivers during the rainy season.

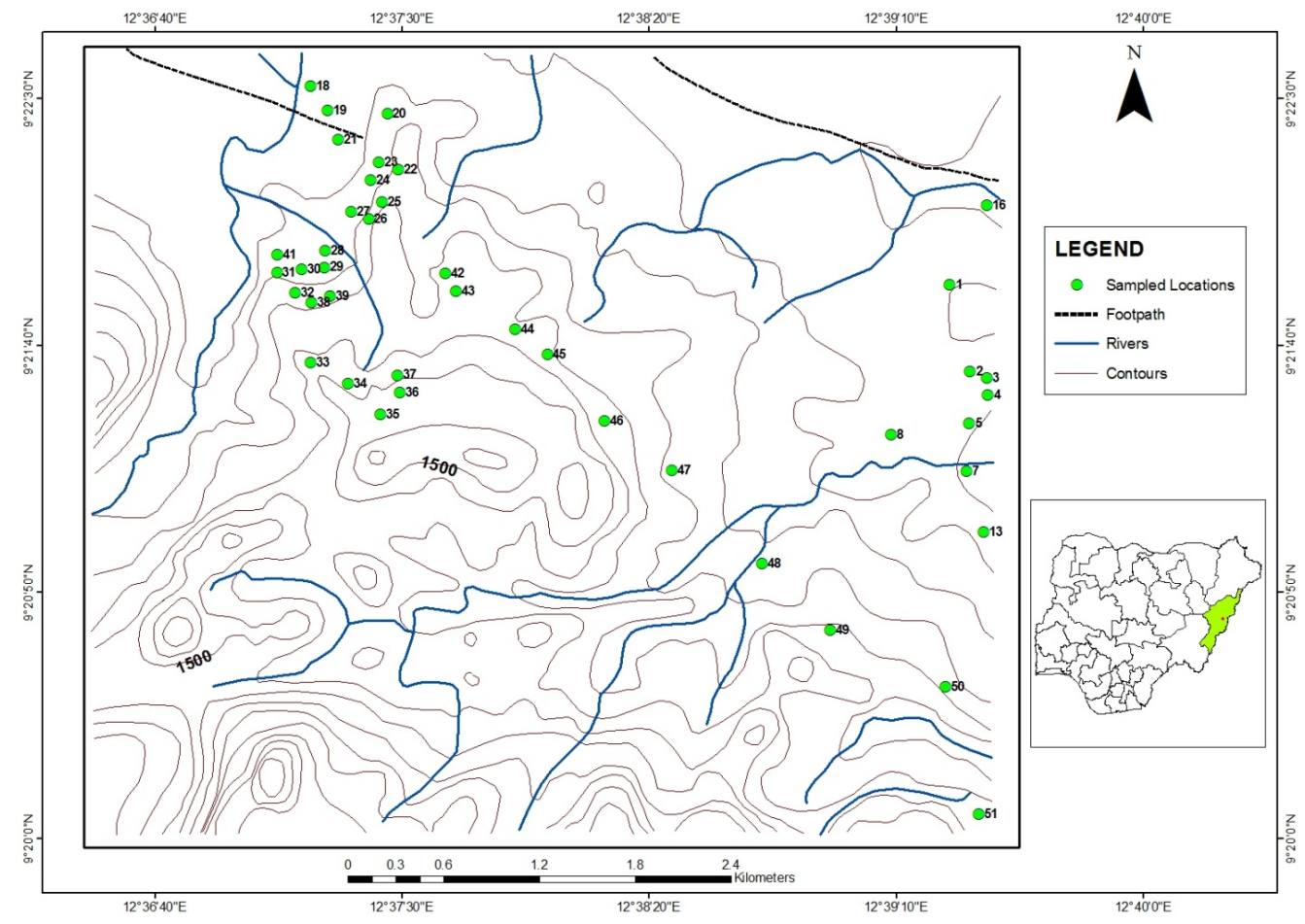

Figure 1. Location of the study area

\subsection{Regional Stratigraphic Setting}

The regional geology and stratigraphy of the Benue Trough have been comprehensively discussed, reviewed and presented by carter et al (1963), offodile (1976), Petters (1982), Whiteman (1982), Nwajide (1990), Ojoh (1992), Akande et al. (1998), Obaje et al (1999) among others. In both arms of the Upper Benue Trough (Figure 2), the continental Albian Bima Sandstone lies unconformably on the Precambrian basement as the oldest known Cretaceous sediment in the region. The Yolde formation which is Cenomanian to Turonian in age lies conformably on the Bima Sandstone. It is made up of a variable sequence of sandstones and shales that marks the transition from continental to marine sedimentation.

\begin{tabular}{|c|c|c|}
\hline \multirow{2}{*}{ AGE } & \multicolumn{2}{|c|}{$\begin{array}{l}\text { UPPER BENUE TROUGH } \\
\end{array}$} \\
\hline & GONGOLA BASIN & YOLA BASIN \\
\hline PALEOCENE & KERRI-FORMATION & \\
\hline MAASTRICHTIAN & & \\
\hline CAMPANIAN & & \\
\hline SANTONIAN & PINDIGA FORMATION & \\
\hline CONIACIAN & & \\
\hline TURONIAN & & \\
\hline CENOMANIAN & YOLDE FORMATION & YOLDE FORMATION \\
\hline ALBIAN & BIMA SANDSTONE & BIMA SANDSTONE \\
\hline
\end{tabular}

Figure 2. A Generalized Stratigraphic Correlation in the Gongola and Yola Basin (After Ojo, 1999) 
The sandstone occurrence is suggestive of a beach environment (Opeloye and Obaje, 2005). In the Gongola Arm, the laterally equivalent Gongila and Pindiga Formations lie conformably on the Yolde Formation. These formations represent full marine incursion into the Upper Benue during the Turonian- Santonian times and are lithologically characterized by dark/black carbonaceous and pale colored limestones and shales with minor sandstones. In the Yola Arm, Dukul, Jessu, Sekule and Numanha are the Turonian-Santonian equivalents of the Gongila and Pindiga Formations. These successions are overlain by the Campanian to Maastrichtian Gombe Sandstone in the Gongola Basin and Lamja Sandstone (Lateral equivalent) in the Yola Basin (Carter et al, 1963). The Tertiary Kerri-Kerri Formation caps the succession west of Gombe in the Gongola Basin. The Gombe Sandstone and the Kerri- Kerri Formation are lithologically composed of sandstones, siltstones and abundant coal intercalations.

\section{Materials and Methods}

A total number of 28 samples were obtained randomly at different outcrop locations of the Bima Sandstone. Eighteen (18) of these samples were subjected to grain size analysis and the remaining ten (10) were used for Thin-section Analyses as detailed below.

\subsection{Grain Size Analysis}

The selected samples were disaggregated, air dried and homogenized. 50g of each sample was sieved using the Ro-tap electro-mechanical sieve shaker (M-Tyler) adjusted to shake for 20 minutes. Quantitative data of cumulative weight percent was plotted against sieves sizes (in $\phi$ unit) to obtain a cumulative plot from which statistical parameters were calculated using formulae by Folk and Ward (1957).

\subsection{Thin- Section Analysis}

Thin section of the ten (10) representative rock samples were prepared and viewed under a petrographic microscope (MEIJI ML 9000). The relative abundance of each mineral constituent and modal composition was estimated, for the purpose of compositional classification. Mineral identification was based on its optical properties outlined in basic optical mineralogical texts.

\section{Result and Discussion}

\subsection{Grain Size Distribution}

The results obtained from the grain size analysis carried out on the clastic sediments are presented in table 1.

\subsubsection{Graphic Mean Size $\left(\mathrm{M}_{\mathrm{Z}}\right)$}

The graphic mean value depicts the average particle size. An evaluation of the sieve analysis result show that the calculated graphic mean size for the sandstones varies from -0.15 to $2.20 \phi$ (very coarse to fine grained), with an average size of $1.10 \phi$ that indicates a medium grained sandstone (Wentworth, 1922). The average value shows the dominance of medium sand-size sediments. More so, $6 \%$ of the rocks in the study area are very coarse grained, $33 \%$ are coarse grained, and 50\% medium grained. This suggests deposition under moderate to high energy (Friedman and sanders, 1978, Eisema 1981). The variability of grain size makes it poorly sorted admixture.

\subsubsection{The Inclusive Graphic Standard Deviation $\left(\sigma_{1}\right)$}

Graphic standard deviation measures the sorting or uniformity of particle size distribution.The inclusive graphic standard deviation computed for the sandstone range from 0.99 to $1.78 \phi$ suggesting moderately to poorly sorted. However, most of the values range from 1.0 to $2.0 \phi$, which indicate poor sorting. The poor sorting is indicative of the fluctuation of the depositing currents (Amaral and Pryor, 1977, Tucker 1988). The poor sorting of the particles may also indicate sediments deposited in fluvio-continental setting (Friedman, 1967). 
Table 1. Result of the statistical parameters obtained for the sandstone in the study area

\begin{tabular}{|c|c|c|c|c|c|c|c|}
\hline SAMPLES & $\begin{array}{l}\text { GRAPHIC } \\
\text { MEAN ( }()\end{array}$ & $\begin{array}{l}\text { STANDARD } \\
\text { DEVIATION }(\phi)\end{array}$ & SKEWNESS & KURTOSIS & $\begin{array}{l}\text { SIMPLE } \\
\text { SKEWNESS }\end{array}$ & $\begin{array}{l}\text { SIMPLE } \\
\text { SORTING }\end{array}$ & INTERPRETATION \\
\hline $\mathrm{S}_{47}$ & 0.79 & 1.50 & 0.39 & 1.44 & 2.21 & 2.93 & $\begin{array}{l}\text { Coarse grained, poorly sorted, } \\
\text { strongly fine skewed, leptokurtic } \\
\text { sandstone. }\end{array}$ \\
\hline $\mathrm{S}_{53}$ & 2.00 & 1.63 & -0.15 & 0.65 & 0.2 & 3.2 & $\begin{array}{l}\text { Fine grained, poorly sorted, coarse } \\
\text { skewed, very platykurtic } \\
\text { sandstone }\end{array}$ \\
\hline $\mathrm{S}_{50}$ & 1.34 & 1.28 & -0.16 & 1.15 & 0.68 & 2.51 & $\begin{array}{l}\text { Medium grained, poorly sorted, } \\
\text { coarse skewed, leptokurtic } \\
\text { sandstone, }\end{array}$ \\
\hline $\mathrm{S}_{23}$ & 1.94 & 1.50 & 0.32 & 1.76 & 2.83 & 3.30 & $\begin{array}{l}\text { Medium grained, poorly sorted, } \\
\text { strongly fine skewed, very } \\
\text { leptokurtic sandstone. }\end{array}$ \\
\hline $\mathrm{S}_{29}$ & 0.82 & 1.14 & 0.08 & 1.14 & 0.82 & 2.04 & $\begin{array}{l}\text { Coarse grained, poorly sorted, near } \\
\text { symmetrical, leptokurtic sandstone }\end{array}$ \\
\hline $\mathrm{S}_{3}$ & 2.20 & 1.58 & 0.03 & 3.42 & 0.80 & 3.4 & $\begin{array}{l}\text { Fine grained poorly sorted, near } \\
\text { symmetrical, extremely leptokurtic } \\
\text { sandstone. }\end{array}$ \\
\hline $\mathrm{S}_{49}$ & 1.38 & 1.78 & 0.36 & 1.84 & 2.95 & 3.41 & $\begin{array}{l}\text { Medium grained, poorly sorted, } \\
\text { strongly fine skewed, very } \\
\text { leptokurtic sandstone. }\end{array}$ \\
\hline $\mathrm{S}_{12}$ & 0.61 & 1.45 & 0.45 & 1.83 & 2.96 & 2.90 & $\begin{array}{l}\text { Coarse grained, poorly sorted, } \\
\text { strongly fine skewed, very } \\
\text { leptokurtic sandstone. }\end{array}$ \\
\hline $\mathrm{S}_{30}$ & 1.58 & 1.25 & 0.55 & 1.72 & 2.48 & 2.30 & $\begin{array}{l}\text { Medium grained, poorly sorted, } \\
\text { fine skewed, very leptokurtic } \\
\text { sandstone. }\end{array}$ \\
\hline $\mathrm{S}_{7}$ & 1.57 & 1.13 & -0.11 & 1.95 & 0.1 & 2.25 & $\begin{array}{l}\text { Medium grained, poorly sorted, } \\
\text { Coarse skewed, very leptokurtic } \\
\text { sandstone. }\end{array}$ \\
\hline $\mathrm{S}_{17}$ & 0.25 & 1.68 & 0.12 & 1.23 & 1.4 & 2.85 & $\begin{array}{l}\text { Coarse grained, poorly sorted, fine } \\
\text { skewed leptokurtic sandstone. }\end{array}$ \\
\hline $\mathrm{S}_{45}$ & 1.08 & 0.99 & -0.11 & 1.46 & 0.02 & 1.78 & $\begin{array}{l}\text { Medium grained, moderately } \\
\text { Sorted, coarse skewed, leptokurtic } \\
\text { sandstone. }\end{array}$ \\
\hline $\mathrm{S}_{25}$ & 1.30 & 1.45 & 0.01 & 1.82 & 1.25 & 2.92 & $\begin{array}{l}\text { Medium grained, poorly sorted, } \\
\text { near symmetrical, very leptokurtic } \\
\text { sandstone. }\end{array}$ \\
\hline $\mathrm{S}_{28}$ & 0.15 & 1.13 & -0.05 & 1.43 & -0.04 & 2.10 & $\begin{array}{l}\text { Coarse grained, poorly sorted, near } \\
\text { symmetrical, leptokurtic sandstone. }\end{array}$ \\
\hline $\mathrm{S}_{33}$ & 1.52 & 1.25 & -0.16 & 1.50 & 0.26 & 2.2 & $\begin{array}{l}\text { Medium grained, poorly sorted, } \\
\text { coarse skewed, leptokurtic } \\
\text { sandstone. }\end{array}$ \\
\hline $\mathrm{S}_{7}$ & 0.18 & 1.07 & -0.02 & 1.27 & 0.05 & 1.75 & $\begin{array}{l}\text { Coarse grained, poorly sorted,near } \\
\text { symmetrical,l eptokurtic sandstone }\end{array}$ \\
\hline $\mathrm{S}_{6}$ & 1.19 & 0.86 & 0.05 & 1.05 & 0.29 & 1.55 & $\begin{array}{l}\text { Medium grained, poorly sorted, } \\
\text { near symmetrica, mesokurtic } \\
\text { sandstonel }\end{array}$ \\
\hline $\mathrm{S}_{5}$ & -0.15 & 1.37 & 0.73 & 0.43 & 1.99 & 2.08 & $\begin{array}{l}\text { Very coarse, poorly sorted, } \\
\text { strongly fine skewed } \\
\text { platykurtic, sandstone }\end{array}$ \\
\hline Average & 1.10 & 1.34 & 0.13 & 1.51 & 1.30 & 2.53 & $\begin{array}{l}\text { Medium grained, poorly sorted, } \\
\text { fine skewed, very leptokurtic } \\
\text { sandstone }\end{array}$ \\
\hline
\end{tabular}

\subsubsection{Inclusive Graphic Skewness ( $\left(\mathrm{Sk}_{1}\right)$}

The graphic skewness is the measure of symmetrical distribution, i.e. predominance of coarse or fine sediments. The inclusive graphic skewness of the sandstone varies from -0.11 to 0.55 (coarse skewed to strongly fine skewed) with an average of 0.13 that indicates that the sandstones are fine skewed and it suggests that the velocity of the depositing current was lower than the average responsible for the deposition of the medium to coarse grained fraction present in the sediments (Sahu, 1964). It also suggests a unidirectional current and selective deposition for the sandstones (Martins, 1965; Valia and Cameroon, 1977; McLaren, 1981). 


\subsubsection{Inclusive Graphic Kurtosis $\left(\mathrm{K}_{\mathrm{G}}\right)$}

The graphic kurtosis relates the peakedness of the distribution and measures the ratio between the sorting in the tails as well as in the central portion of the curve. If the central portion shows better sorting than the tails, then curve is termed leptokurtic .It is platykurtic if the tails are better sorted and if both are equally sorted, then it is mesokurtic. The values obtained for kurtosis indicates that the sediments are mainly leptokurtic, however they range in values from 0.43 to 3.42 indicating a very platykurtic to extremely leptokurtic sandstone. The preponderance of leptokurtic and positively skewed curves is consonant with Friedman's (1962) observation that most sands are leptokurtic and positively or negatively skewed.

\subsection{Mineralogical Composition and Grain Morphology}

The result of the thin-section analysis carried out in the study area is presented in Table 2. The modal composition of quartz, feldspar and rock fragment is presented in Table 3 and this was used for the construction of Ternary diagrams (Figure 3 and 4). Thin-section studies revealed that the average modal mineralogical composition of the sandstone comprise of approximately $66.6 \%$ quartz, $21 \%$ feldspar and $12.4 \%$ rock fragments.

$\mathrm{K}$-feldspar occurs as the dominant feldspar present in the rocks. Generally, the preservation of feldspar requires rapid uplift, erosion, and rapid sedimentation. Climate also plays a role. When feldspar is subjected to hot humid conditions, it weathers to clay minerals, but very rapid erosion and short transport history which characterize a high relief source area favour the preservation of feldspar (Tucker, 1988). According to Haruna et al (2013), the basis for the possible paleoclimatic interpretation of the source area for the sediments is the detrital clay mineral composition (Predominantly Kalsinite) of the Bima sandstone and the plaeoclimatic setting is the humid tropics. This abundance of kalsinite is typical of acid tropical areas where leaching or alteration is intensive. Hence the presence of both fresh and weathered angular to subangular shaped feldspar in the sediments is indicative of their derivation and deposition in a hot and humid climate in which feldspar preservation was guaranteed as a result of rapid erosion in relation to weathering as well as short transport path for the ancient sediments. Cement constitutes a significant portion in some of the samples ranging from 2 to $10 \%$ with an average of 5.5\% in the total samples studied. Three different types of cement were recognized and these include iron oxide, silica and clay minerals, with the latter rarely observed in the samples studied. The iron oxide occurs as clots between grains especially in areas where they are not in contact with each other, while silica cement occurs as microcrystalline aggregates in pores as overgrowth on silica grains.

Table 2. Mineralogical composition of sandstone in the study area

\begin{tabular}{cccccccc}
\hline Sample & Quartz (\%) & Feldspar (\%) & Cement (\%) & Matrix (\%) & Mica (\%) & Rock fragment (\%) & $\begin{array}{c}\text { Heavy } \\
\text { Minerals (\%) }\end{array}$ \\
\hline $\mathrm{S}_{38}$ & 61 & 17 & 4 & 1 & 1 & 11 & 5 \\
$\mathrm{~S}_{21}$ & 60 & 22 & 2 & 3 & 3 & 10 & 3 \\
$\mathrm{~S}_{7}$ & 60 & 15 & 5 & 3 & 2 & 10 & 5 \\
$\mathrm{~S}_{28}$ & 60 & 18 & 3 & 1 & 4 & 7 & 2 \\
$\mathrm{~S}_{29}$ & 60 & 20 & 5 & 2 & 3 & 7 & 3 \\
$\mathrm{~S}_{12}$ & 60 & 16 & 4 & 2 & 4 & 12 & - \\
$\mathrm{S}_{40}$ & 47 & 22 & 8 & 4 & 4 & 15 & - \\
$\mathrm{S}_{50}$ & 60 & 17 & 5 & 1 & 1 & 16 & 2 \\
$\mathrm{~S}_{17}$ & 50 & 17 & 10 & 4 & 4 & 13 & 4 \\
$\mathrm{~S}_{30}$ & 55 & 17 & 9 & 3 & 6 & & 6 \\
\hline
\end{tabular}

Table 3. Modal composition of sandstone in the study area

\begin{tabular}{cccc}
\hline Sample & Quartz (\%) & Feldspar (\%) & Rock fragment (\%) \\
\hline $\mathrm{S}_{38}$ & 69 & 19 & 12 \\
$\mathrm{~S}_{21}$ & 65 & 24 & 11 \\
$\mathrm{~S}_{7}$ & 70 & 18 & 12 \\
$\mathrm{~S}_{28}$ & 71 & 21 & 8 \\
$\mathrm{~S}_{29}$ & 69 & 23 & 8 \\
$\mathrm{~S}_{12}$ & 68 & 18 & 14 \\
$\mathrm{~S}_{40}$ & 56 & 26 & 18 \\
$\mathrm{~S}_{50}$ & 65 & 18 & 17 \\
$\mathrm{~S}_{17}$ & 63 & 21 & 16 \\
$\mathrm{~S}_{30}$ & 70 & 22 & 8 \\
Mean & 66.6 & 21 & 12.4 \\
\hline
\end{tabular}


Comparing the Ternary diagrams (Figure 3 and 4) with similar works of Mcbride (1963) and Pettijohn et al (1987), the sandstones in the study area are classed as lithic subarkoses, subarkoses and lithic arkoses.

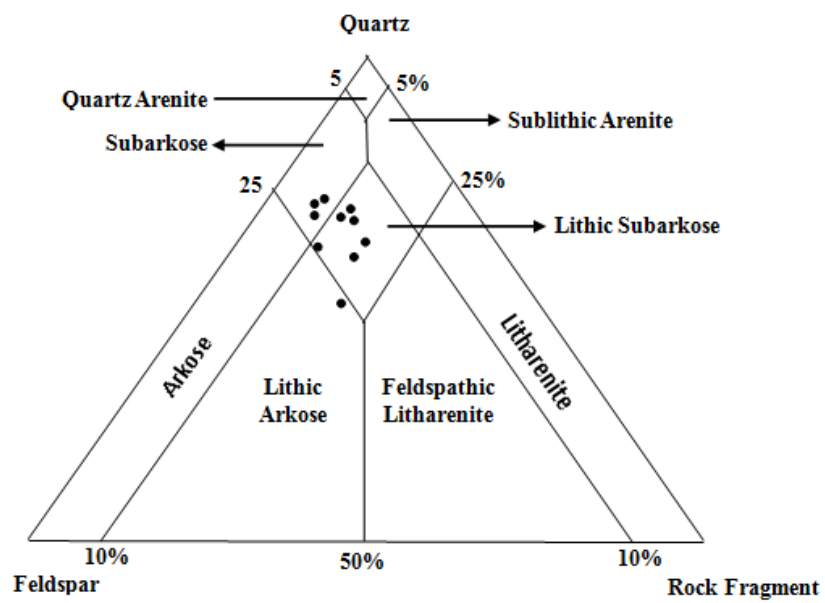

Figure 3. Ternary diagram showing the modal composition of the sandstone facies in the study area (After Mcbride, 1963)

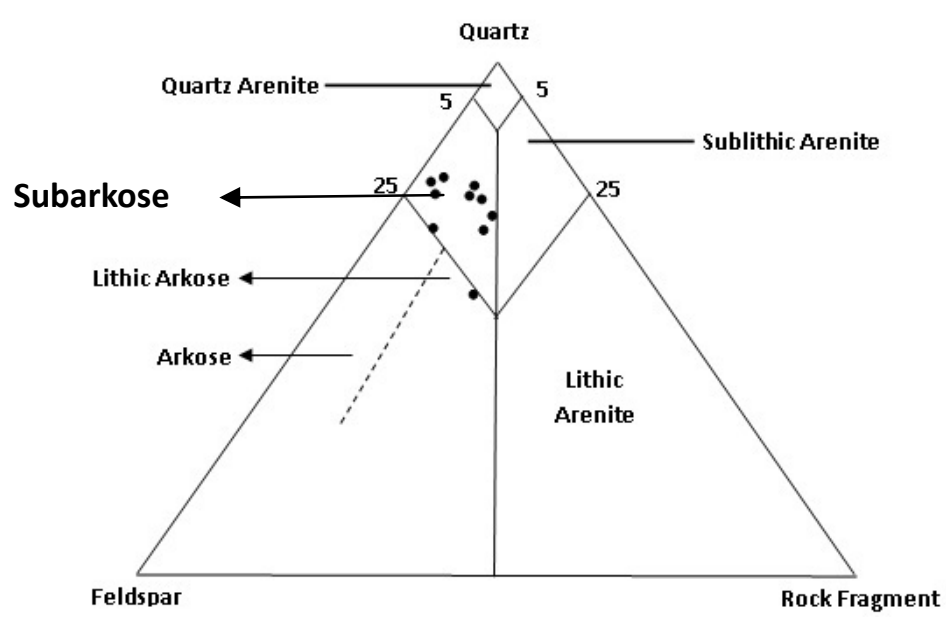

Figure 4. Ternary diagram showing the modal composition of the sandstone facies in the study area (After Pettijohn et al, 1987)

Table 4 shows the summarized petrographic description of the sandstone in the study area. The morphology of framework grains of sandstones often varies with grain size and mineralogy. These parameters are in turn dependent on the type of source rock as well as the degree of weathering and abrasion (Tucker, 1988).

Table 4. Petrographic description of sandstone in the study area

\begin{tabular}{cccc}
\hline Sample & Grain size & Grain shape & Sorting \\
\hline $\mathrm{S}_{38}$ & Fine & Sub rounded to rounded & Well sorted \\
$\mathrm{S}_{21}$ & Medium & Subangular rounded & Poorly sorted \\
$\mathrm{S}_{7}$ & Coarse & Angular & Poorly sorted \\
$\mathrm{S}_{28}$ & Medium & Subangular-rounded & Moderately sorted \\
$\mathrm{S}_{29}$ & Medium & Angular & Poorly sorted \\
$\mathrm{S}_{12}$ & Coarse & Angular- Subangular & Moderately sorted \\
$\mathrm{S}_{40}$ & Coarse & Angular- Subangular & Poorly sorted \\
$\mathrm{S}_{50}$ & Medium & Sub-angular & Moderately sorted \\
$\mathrm{S}_{17}$ & Medium & Angular- subangular & Moderately sorted \\
$\mathrm{S}_{30}$ & Coarse & Angular- Subangular & Poorly sorted \\
\hline
\end{tabular}


Majority of the framework grains varies from angular to sub-angular and occasionally sub-angular to rounded in shape. There are very scanty well rounded coarse grains .Quartz was observed to exhibit better roundness than feldspars, rock fragments and mica. Feldspars and lithic fragments occur in lesser quantities as framework grain. The matrix is mainly composed of tiny angular (sometimes irregularly shaped) micas, feldspar and quartz which fill part of the intergranular voids and acts as subordinate binder to the framework grain. From the grain morphology, it may be inferred that the sandstones were not transported for a long distance before their deposition (Pettijohn, 1975).

\subsection{Depositional Environment}

Several researchers have employed different methods and criteria to distinguish depositional environment from grain size distributions; Folk and Ward, (1957), Friedman (1961, 1967), Moiola and Weiser, (1968), Sahu, (1964) and others.

Comparing the bivariate plots of Simple Skewness against Simple Sorting (Figure 5), Graphic means versus Standard deviations (Figure 6) and Skewness versus standard deviation (Figure 7) with similar works of Friedman (1967), all the samples plotted are indicative of fluvial origin. The dominance of medium to coarse grained particles for the sandstones in the study area probably points to a moderate to high energy depositional environment that may be likened to those of a fluvial setting.

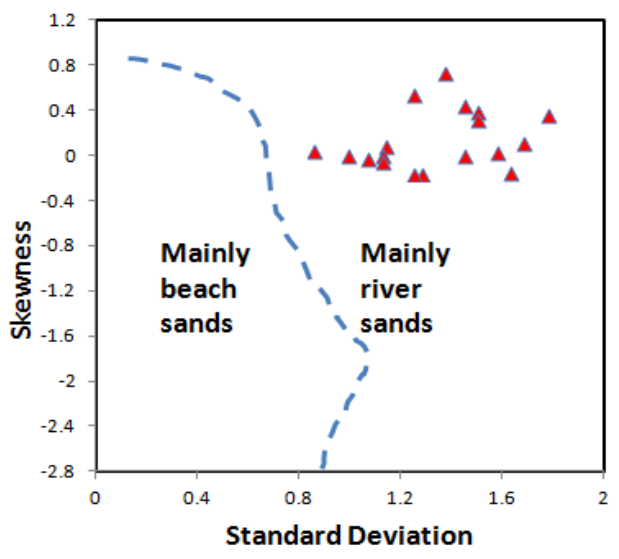

Figure 5. Bivariate Plot of Skewness versus Standard deviation

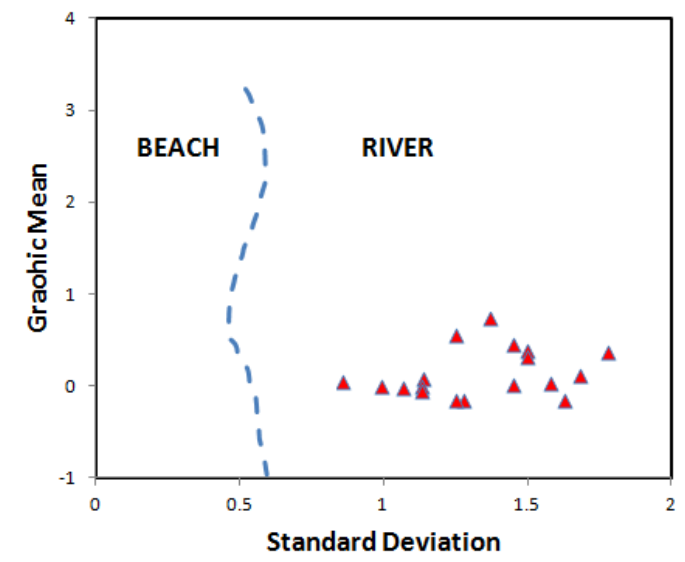

Figure 6. Bivariate Plot of Graphic Mean versus Standard deviation

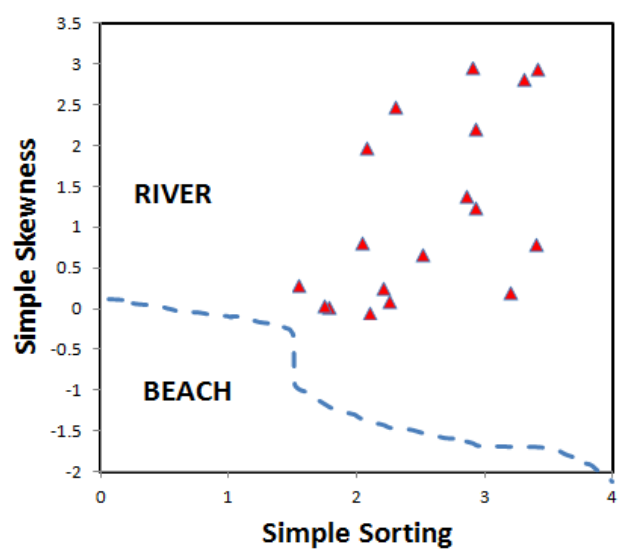

Figure 7. Bivariate Plot of Simple Skewness versus Simple sorting

\section{Conclusion}

Textural and compositional studies of sediments from parts of the Bima Sandstone have led to some notable conclusions. The sandstones are composed of fine to coarse grains which are mainly angular to sub-angular and occasionally sub-angular to rounded in shape and moderately sorted to poorly sorted. This variability in grain size which makes it a poorly sorted admixture is indicative of the fluctuation of the depositing currents. The modal mineralogical composition consists averagely of $66.6 \%$ quartz, $21 \%$ feldspars and $12.4 \%$ rock fragments. These sandstones are classed as lithic subarkoses, subarkoses, and lithic arkoses deposited in a fluvial setting where current energy was mainly moderate to high.The appreciable amount of feldspar, the dominance of 
subangular to angular grain shape and the poorly sorted nature of the sandstones suggest that they are texturally and mineralogically immature sediments.

\section{References}

Akande, S. O., Ojo, O. J., Erdmann, B. D., \& Hetenyi, M. (1998). Paleoenvironments, source rock potential and thermal maturity of the upper Benue Rift basins, Nigeria: Implication for hydrocarbon exploration. Organic Geochemistry, 29, 531-542.

Amaral, E. A., \& Pryor, W. A. (1977). Depositional environment of St. Peters sandstone deduced by textural analysis. Journal of Sed. Pet., 47(1), 32-52.

Benkhelil, J. (1987). Cretaceous deformation, Magmatism and Metamorphism in the lower Benue Trough, Nigeria. Geol. Journal, 22, 467- 498.

Benkhelil, J. (1989). The origin and evolution of the Cretaceous Benue Trough, Nigeria. Journal of African Earth Sciences, 8, 251-282.

Burke K. C., Dessauvagie, T. F. J., \& Whiteman, A. J. (1972). Geological history of the Benue Valley and adjacent area. In T. F. J. Dessauvagie, \& A. J. Whiteman (Eds.), African Geology (pp. 187- 206). Ibadan University press.

Burke, K. C., \& Whiteman, A. J. (1973). Uplift, rifting and the break up of Africa .In: Implication of Continental drift to Earth sciences (Edited by Tarling D.H and Runcorn, S. K), 735-755.

Carter, J. D., Barber, W., Tait, E. A., \& Jones, G. P. (1963). The Geology of parts of Adamawa, Bauchi and Bornu provinces in North- Eastern Nigeria. Bull. Geol. Surv. Nigeria, 30, 1- 99.

Cratchley, C. R., \& Jones, G. P. (1965). An interpretation of the Geology and Gravity Anomalies of the Benue Trough valley, Nigeria overseas Geological Survey. Geophysical paper, 1, 1-26.

Eisema, D. (1981). Supply and deposition of suspended matter in the North Sea. Special Publication of the International Association of Sedimentologists, 5, 415-428.

Folk, R. L., \& Ward, M. C. (1957). Brazos River bar: A study of the significance of grain size parameters. Journal of Sedimentary Petrology, 27, 3-26.

Freeth, S. J. (1978). Tectonic activity in West Africa and the Gulf of Guinea since Jurassic times- an explanation based on membrane Tectonics. Earth Planet, 38, 298-300.

Friedman, G. M. (1961). Distinction between dune, beach and river sands from textural characteristics. Journal Sed. Pet., 31(4), 514-529.

Friedman, G. M. (1962). On sorting, sorting coefficients and the log normality of the grainsize distributions of sandstones. Journal Geol., 70, 737-753.

Friedman, G. M. (1967). Dynamic processes and statistical parameters compares for size frequency distribution of beach and river sands. Journal Sed. Pet., 37, 327-354.

Friedman, G. M. (1979). Difference in size distributions of population of particles among sands of various origins. Sedimentology, 26, 3-32.

Friedman, G. M., \& Sanders, J. E. (1978). Principle of Sedimentology.John.Wiley and Sons Inc.792pp.

Grant N.K (1971). The South Atlantic, Benue Trough and Gulf of Guinea Cretaceous Triple Junction. Soc. Amer. Bull., 82, 2295-2298.

Haruna, I. V, Dio, C. J, Maunde, A., \& Raji, A. S. (2013). Provenance and Paleoenvironmental Study of Bima sandstone in the Upper Benue Trough, N.E Nigeria. International Research Journal of Earth Sciences, 1(2), P. 1-11.

King, L. C. (1950). Outline land disruption of Godwanaland Geol. Mag. 87, 353-359.

Martins, L. R. (1965). Significance of skewness and kurtosis in environment interpretation. Journal of Sed. Pet., 35(3), 768-770.

Mcbride, E. F. (1963). A classification of common sandstones. Journal of sedimentary Petrology, 33, 664-669

McLaren, P. (1981). An interpretation of trends in grain size measure. Journal of Sed. Pet., 51(2), 611-624.

Moiola, R. J., \& Weiser, D. (1968). Textural parameters: An evolution. Journal of Sed. Pet., 38, 45-53.

Nwajide, C. S. (1990). Cretaceous sedimentation and petrography of the Central Benue Trough in Ofoegbu. In 
C.O. (Ed.), The Benue Trough structure and evolution (pp. 19-38). Earth Sciences monograph series viewed and Sohn Wiedsbaden, Germany.

Obaje, N. G., Abaa, S. I., Najime, T., \& Suh, C. E. (1999). Economic geology of Nigerian Coal resources- a brief review. African geosciences Review, 6, 71-82.

Offodile, M. E. (1976). The geology of the Middle Benue valley, Nigeria, publication of the Paleo. Inst.of the University of Uppsala, special publication, 4, 1-166.

Ofoegbu, C. O. (1984). A model for the tectonic evolution in the Benue Trough of Nigeria. Geol. Rundach, 37, 1007-1018.

Ojo, O. J. (1999). Depositional Environments, Palynological and organic Geochemical studies of Gongola and Yola Basins, Nigeria: Implications for Hydrocarbon Potential. Unpubl. Ph.D.The University of Ilorin, Ilorin. $355 \mathrm{P}$.

Ojoh, K. A. (1992). The southern part of the Benue Trough (Nigeria) Cretaceous stratigraphy, basin analysis, paleo-oceanography and geogdynamic evolution in the equatorial domain of the South Atlantic: Nigeria Association of Petroleum Explorationists (NAPE) Bulletin, 7, 131-152.

Olade, M. A. (1975). Evolution of Nigeria's Benue Trough (Aulacogen). A tectonic Model: Geological magazine $112,575-583$

OPeloye, S. A., \& Obaje, N. G. (2005). Ostracods from the Yola Arm, Upper Benue Trough, Nigeria. Global Journal Geol. Sc., 3(2), 179-185.

Petters, S. W., \& Ekweozor, C. M. (1982). Petroleum geology of the Benue Trough and the southeastern Chad Basin, Nigeria. AAPG Bulletin, 66, 1141-1149.

Pettijohn, F. J. (1975). Sedimentary rocks, Harper and row. New York 628pp.

Pettjohn, F. J, Potter, P. E., \& Siever, R. (1987). Sand and Sandstone (2nd ed). Springer-Verlag, Newyork, 618pp.

Sahu, B. K. (1964). Depositional Mechanism from the size analysis of clastie sediments. Journal Sed. Pet., 34(1), 78-83.

Schlumberger (1989). Log Interpreation, Principles And Application: Schlumberger Wireline And Testing, Houston, Texas, 21-89.

Tucker, M. E. (1988). Sedimentary Petrology: An Introduction. ELBS ed, Blackwell Scienti. Publ.252pp.

Valia, H. S., \& Cameroon, B. (1977). Skewness as a paleoenvironmental indicator, Journal Sed. Pet., 47(2), 84-793.

Wentworth, C. K. (1922). A scale and class terms for clastic sediments. Journal Geol, 30, 377-392.

Whiteman, A. J. (1982). Nigeria its Petroleum Geology, Resources and Potential. Graham and Trotman, London, 2, 394.

Wright, J. B. (1981). Review of the origin and evolution of the Benue Trough in Nigeria. Earth Evolution, 2, 98-103.

\section{Copyrights}

Copyright for this article is retained by the author(s), with first publication rights granted to the journal.

This is an open-access article distributed under the terms and conditions of the Creative Commons Attribution license (http://creativecommons.org/licenses/by/3.0/). 